\title{
The influence of accounting ethics on quality of financial reports among accounting practitioners in ibadan, oyo state, nigeria
}

\author{
Osunwole, Olatunji Oludayo ${ }^{1}$ \\ ${ }^{I}$ Department of Accountancy, Faculty of Financial Studies, \\ Osun State Polytechnic, Iree. Nigeria. \\ E-mail: osunwoletunji@gmail.com +2348035081689 \\ Adeyemi, Ola Adewale ${ }^{2}$ \\ ${ }^{2}$ Department of Banking and Finance, Faculty of Financial Studies, \\ Osun State Polytechnic, Iree. Nigeria. \\ E-mail: adeyemi246@yahoo.com +2348167360267 \\ Dunsin, Abimbola Tolulope $e^{3}$ \\ ${ }^{3}$ Department of Accountancy, Faculty of Financial Studies, \\ Osun State Polytechnic, Iree. Nigeria. \\ E-mail: abimboladusin9@gmail.com +2348064839840
}

\begin{abstract}
This study investigated the impact of relationship marketing on consumer buying behavior in the food and This study examined the influence of accounting ethics on the quality of financial reports of Nigerian firms. Specifically, the study focused on the influence of accounting ethics on relevance and faithful representation of financial information of Nigerian firms. Descriptive survey design was utilized to conduct the study. The target population for this study was over 300 accounting practitioners distributed over deposit money banks, Audit firms, educational tertiary institutions and small and medium scale industries in Ibadan, Oyo state. Slovin's formula was used to determine the sample size, while stratified and convenience sampling techniques was employed to select 171 respondents that participated in the study. Primary data was used for the study. Questionnaires were used as data collection tools. The study results established that accounting ethics ( $\beta=$ $0.282 ; p<0.05)$ and $(\beta=0.234 ; p<0.05)$ had positive and significant effect on relevance and faithful representation of financial information respectively. The study concluded that high ethical standard is fundamental in achieving an objective, reliable and transparent financial report. The study recommends that firms in Nigeria should put in place ethics and compliance department to direct and monitor ethics implementation in their day-to-day operations and that firms reporting structure should adhere strictly to the financial reporting framework issued by the International Financial Reporting Standards for better and more acceptable financial reports.
\end{abstract}

Keywords: Financial Reporting Quality, Accounting ethics, Relevance, Faithful representation, Accounting Practitioners

\section{Introduction}

The downfall of some companies and increased levels of prominent frauds over the past two decades had resulted to the question of integrity in accounting profession. The global scandals, such as Enron, WorldCom, Bank of Credit, Global Crossing, Commerce International, Cadbury, Parmalat, and Polly Peck have questioned the efficiency in corporate mechanisms of governance (Zeghal \& Mhedhbi, 2016). There are questions also on the quality and credibility of financial reports and audit functions respectively, thus generating to amplified demands for professional ethics in financial reporting profession. This is considering that the purposes for ensuring the performance of the firm relies squarely on the corporate financial reports.

Ethics is a term subject to numerous, sometimes conflicting, interpretations and as such ethical problems are a very relevant issue present in many aspects of real life. Ethics can be examined through several branches and under several grids of analysis, modern or classic (Filipe, Alberto, Ferreira, 2011). 
A distinguishing mark of the accounting profession is its acceptance of the responsibility to act in the public interest (IFAC, 2006). Key qualities which appear in the codes of ethics of professional bodies include independence, integrity, objectivity, competence and judgement. For example, the Institute of Chartered Accountant in England and Wales (ICAEW) introduction to its guide to professional ethics includes a list of five fundamental principles which either expressly mentions or clearly implies all of these qualities, along with other related qualities such as honesty, fair-dealing, truthfulness, courtesy, skill and diligence (Gowthorpe, 2005). The history of the need for accountants to establish high ethical standards began with the failure of the technology bubble followed by the collapse of Enron, WorldCom and Arthur Anderson among others (Rockness \& Rockness, 2010).

With an understanding of the ethical practices, accountants will be able to overcome ethical dilemmas, thereby making informed decisions and right choices, which may out-rightly not benefit the company but the public who relies on the report from the accountant (Ramanna \& Sletten, 2014). Additionally, the accounting profession is informed by service to the public and therefore it prescribes to its own ethical standards. The distinguishing feature of the accounting profession is its focus on serving public interest and acting professionally while observing high standards beyond the fees paid by the client. The accountant has an obligation to cater for the interest of all stakeholders.

Alexander and Britton (2000) cited in Enofe, Edemenya and Osunbor (2015) noted that the fundamental objective of financial reports is to communicate economic measurements of information about resources and performance of the reporting entity useful to those having reasonable rights to such information. IASB (2010) noted that providing high quality financial reporting information is important because it will positively influence capital providers and other stakeholders in making investment, credit and similar resource allocation decisions enhancing overall market efficiency. The quality of financial reporting indicates a limit in which the financial reports of a company, its economic status, and functions, which are measured over period of time, are presented honestly (Talebinia, Salehi \& Jabberzabe, 2011). Truthfulness of the trust in the financial reporting system depends on far more than the actions and decisions of individuals or sophisticated mechanisms for the whole system (Enderl, 2006). Therefore, truthfulness of the trust in the financial reporting system cannot be a matter of either personal or institutional ethics alone (Brenkart, 2004). Behaving ethically in accounting is more important than auditing because accounting system prepares financial statements for auditing (Mahdavikhou \& Khotanlou, 2011).

Accountants have obligations to shareholders, creditors, employees, suppliers, the government, the accounting profession and the public at large. In other words, their obligations go beyond their immediate client. Decisions made on information provided by accountants can materially affect the lives of any or all of these stakeholders. Therefore behaving ethically is an essential and expected trait (Carroll, 2005). As a result, an accountant is responsible for the consequences of his moral choices not only for his own life but also on the lives of other people. An accountant who commits fraud not only ruins his own moral being but also harms the interests of the other members of society who depend on him (Catacutan, 2006). Accounting ethics is important to accountants and those who rely on information provided by accountants because ethical behavior entails taking the moral point of view. This can be seen as a formal method of declaring to all that the occupation can be trusted (Carroll, 2005). Internalizing and developing accounting professional ethics in accounting profession lead to promoting the quality of financial reporting (Mahdavikhou, 2010).

\section{Statement of the Problem}

Individual from time to time have to face ethical dilemmas and the problem of weakness of will. Accountants are no different. In the working life of an accountant they encounter numerous situations where they are tempted to choose between right or wrong. That is why a feature of accounting's claim to professionalism is its commitments to ethical standards. This involves an assurance that the accounting bodies and their members will not pursue their material self-interests in ways that conflict with their duties to the public interest (Appah, 2010). Mathews and Perera (1996) observe that every 
profession has a built in code of ethics to compel ethical behavior on its members. The rationale for this is obvious. The Nigerian society over the years has witnessed its fair share of corporate scandals in the financial (Societe General Bank, Oceanic Bank etc) and non-financial (Cadbury Plc and African Petroleum) sectors of the economy (Ogbonna, 2010). Ogbonna (2010) argues that any organization that lacks ethical consideration may not survive for a long time to achieve its desired goals and objectives and that of its stakeholders. These failures of corporate entities in the opinion of Ogbonna and Appah (2011) have been attributed to accountants not adhering to the codes of conduct evidenced not only in the contents of financial statements but also in its reliability by end users. Hence adequate care has to be taken on how these financial statements are presented. Aguolu (2006) says that these failures have brought to greater scrutiny the work of the accountant from both within the profession and from outside. Several ethical issues have been discussed in recent times ranging from conflict of interest, insider's dealings, objectivity, acceptance of gifts etc. scholars are of the opinion that all these ethical issues affect the quality of financial statements. The code of corporate governance (2011) cited in Enofe, Edemenya and Osunbor (2015) provided for the composition of an ethics committee in an organization where the committee is responsible for deliberating on ethical issues as well as upholding ethical standards in the organization. This has not really yielded the right result as intended as some of the scandals over the past decade have been traced to ethical issues where most times management and auditors compromised integrity for personal and selfish gain to the detriment of the organization. According to Enofe, Edemenya and Osunbor (2015) Enron manipulated its statement through off balance sheet financing because they lacked independence from senior executives, Cadbury overstated its audited financial statements, African petroleum concealed its indebtedness to the tune of 22 billion, the financial sector crisis also witnessed few years ago also revealed that the banks connived with the auditors to issue a true and fair view. A critical look at all these cases show that they all were as a result of the violation of ethical practices, hence there's need to critically appraise ethical issues in an organization and how they affect financial reporting quality. This study therefore examines the relationship between accounting ethics and the fundamental qualitative characteristics of financial reporting of relevance and faithful representation of financial information of Nigerian firms.

\section{Research Objectives}

The main objective of this study is to examine the influence of accounting ethics on the quality of financial reports of Nigerian firms. The specific objectives are to;

i. Examine the influence of accounting ethics on the relevance of financial information of Nigerian firms

ii. Determine the influence of accounting ethics on the faithful representation of financial information of Nigerian firms

\section{Research Questions}

The following research questions were answered in this study

i. What is the influence of accounting ethics on the relevance of financial information of Nigerian firms?

ii. To what extent do accounting ethics influence the faithful representation of financial information of Nigerian firms?

\section{Research Hypotheses}

The following research hypotheses were tested in this study

$\mathrm{H}_{01}$ : Accounting ethics does not have significant influence on the relevance of financial information of Nigerian firm.

$\mathrm{H}_{02}$ : Accounting ethics does not have significant influence on the faithful representation of financial information of Nigerian firm.

\section{Conceptual Review \\ Accounting Ethics}

Ethics is a term subject to numerous, sometimes conflicting, interpretations (Agwor \& Okafor, 2018). 
Ethical problems are a very relevant issue present in many aspects of real life. These situations can be examined through several branches and under several grids of analysis, modern or classic (Filipe, Alberto and Ferreira, 2011). A distinguishing mark of the accountancy profession is its acceptance of the responsibility to act in the public interest (IFAC, 2005). Key qualities which appear in the codes of ethics of professional bodies include independence, integrity, objectivity, competence and judgment. For example, the ICAEW's introduction to its 'Guide to Professional Ethics' (ICAEW, 1997) includes a list of five fundamental principles which either expressly mentions or clearly implies all of these qualities, along with other related qualities such as honesty, fair-dealing, truthfulness, courtesy, skill and diligence (Gowthorpe, 2005).

The rapid development of human society and social relationships which is complex necessitates the constant flux of fiduciary relationship management that is ethically acceptable. One professional development efforts needed in response to these changing conditions evolve in the form of professional codes of conduct and standards. Thus, increasing social demands in the range of accounting responsibilities in the complex web of social contracts makes the establishment of standard practice and professional behaviour expected of the accountant, inevitable. This explains why accounting services are provided under the supervision of a professional association, (Saghafi, Rahmani, \& Rabie, 2010).

The professional accountant is expected to provide true and accurate picture of the performance of an entity even in the face of conflicting interest involving his personal interest. Such display of professional discipline, which is the hallmark of professional objectivity, no doubt, engenders reliability, continued trust and public confidence in the accounting profession, which should further reinforce the intellectual and practical adherence to the professional standards of conduct. More so, it is believed that such professional discipline also enhances the desirable quality of the final products of the accounting profession. Such desirable qualities as faithful representation of facts, relevance and reliability of facts so presented, understandability of facts and timeliness of facts, are enhanced when the public accountant is seen to be so professionally disciplined in conduct.

\section{Qualitative Characteristics of Financial Reporting}

According to IASB, the essential principle of assessing the financial reporting quality is related to the faithfulness of the objectives and quality of disclosed information in a company's financial reports. These qualitative characteristics enhance the facilitation of assessing the usefulness of financial reports, which will also lead to a high level of quality. To achieve this level, financial reports must be faithfully represented, comparable, verifiable, timely, and understandable. Thus, the emphasis is on having transparent financial reports, and not having misleading financial reports to users; not to mention the importance of preciseness and predictability as indicators of a high financial reporting quality (Gajevszky, 2015). As it is defined in the Conceptual Framework for Financial Reporting of the FASB and the IASB, there are agreed upon elements of high quality financial reporting. The qualitative characteristics of financial reporting quality include: relevance, faithful representation, understandability, comparability, verifiability, and timeliness.

They are divided into fundamental qualitative characteristics and enhancing qualitative characteristics. A theoretical explanation for each of these terms emphasizes their importance as qualitative characteristics, and also indicates what qualities are considered fundamental among different frameworks.

\section{Relevance}

Relevance is closely associated with the terms usefulness and materiality. Relevance illustrates the capability of making decisions by users. When information in financial reports influences users in their economic decisions, it is sad that this information has the quality of relevance. Also, when this information assists users to evaluate, correct, and confirm current and past events, it is useful. The usefulness of making a decision is an important part of relevance and is consistent with the conceptual framework (Cheung, Evans, \& Wright, 2010). Fair value is considered one of the highly significant indicators of relevance. Using fair value in an entity, as a basis for measurement, is an indicator of a 
high level of relevance in financial reporting information (Beest, Braam, \& Boelens, 2009). Annual reports have a crucial role in determining the level of relevance by disclosing forward-looking information, disclosing information about business opportunities and risks, and providing feedback on how major market events and significant transactions affected entities (Beest, Braam, \& Boelens, 2009).

\section{Verifiability}

Verifiability is another critical factor of financial reporting quality. In financial reporting, information must have the quality of been verifiable and reliable in order to be useful. These qualities are achieved when information, which users depend upon, is free from bias and material mistakes. Verifiability is analyzed based on the qualities of faithful, reliable, and neutral information (Cheung, Evans \& Wright, 2010).

\section{Comparability}

Comparability is the concept of allowing users to compare financial statements to determine the financial position, cash flow, and performance of an entity. This comparison allows users to compare across time and among other companies in the same period. Cheung, Evans and Wright (2010) remarked that comparability demands that identical events in the two situations will be reflected by identical accounting facts and figures and different events will be reflected by different accounting facts and figures in a way which quantitatively reflects those differences in a comparable and easily interpretable manner. (Cheung et al.2010).

To indicate this point, the notes in financial reports should disclose and explain all the changes in accounting policies and the implications of these changes, not to mention the importance of consistency in applying accounting policies and principles. Also, the current accounting period results can be compared with the ones from previous periods. Lastly, presenting financial index numbers and ratios contributes to the comparison with other organizations (Beest et al.2009).

\section{Understandability}

Understandability is one of the essential qualities of information in financial reports. Achieving the quality of understandability is through effective communication. Thus, the better the understanding of the information from users, the higher the quality that will be achieved (Cheung, Evans, \& Wright, 2010). It is one of the enhancing qualitative characteristics that will increase when information is presented and classified clearly and sufficiently. When annual reports are well organized, users can comprehend what their needs are (Beest, Braam, \& Boelens, 2009). Usage of graphs and tables helps to present information clearly, and the usage of language and technical jargon can be followed easily.

\section{Timeliness}

Timeliness is another enhancing qualitative characteristic. Timeliness illustrates that information must be available to decision makers before losing its powerful and good influences. When assessing the quality of reporting in an annual report, timeliness is evaluated using the period between the yearend and the issuing date of the auditor's report, the period of days it took for the auditor to sign the report after the financial year-end (Beest, Braam, \& Boelens, 2009).

\section{Faithful Representation}

Faithful representation is the concept of reflecting and representing the real economic position of the financial information that has been reported. This concept has the value of explaining how well the obligations and economic resources, including transactions and events, are fully represented in the financial reporting. Moreover, this quality has neutrality as a sub notion which is about objectivity and balance. According to Willekens (2008), researchers concluded that the auditors' report adds value to financial reporting information by providing reasonable assurance about the degree to which the annual report represents economic phenomena faithfully. Additionally, how business organizations are controlled and directed affects the faithful presentation quality; this, in fact, is represented as a corporate governance factor when there is extensively disclosed information on corporate governance issues in the annual report (Beest, Braam, \& Boelens, 2009). Besides, the annual report clarifies assumptions and estimates and explains the usage of the accounting principles in the company clearly. 


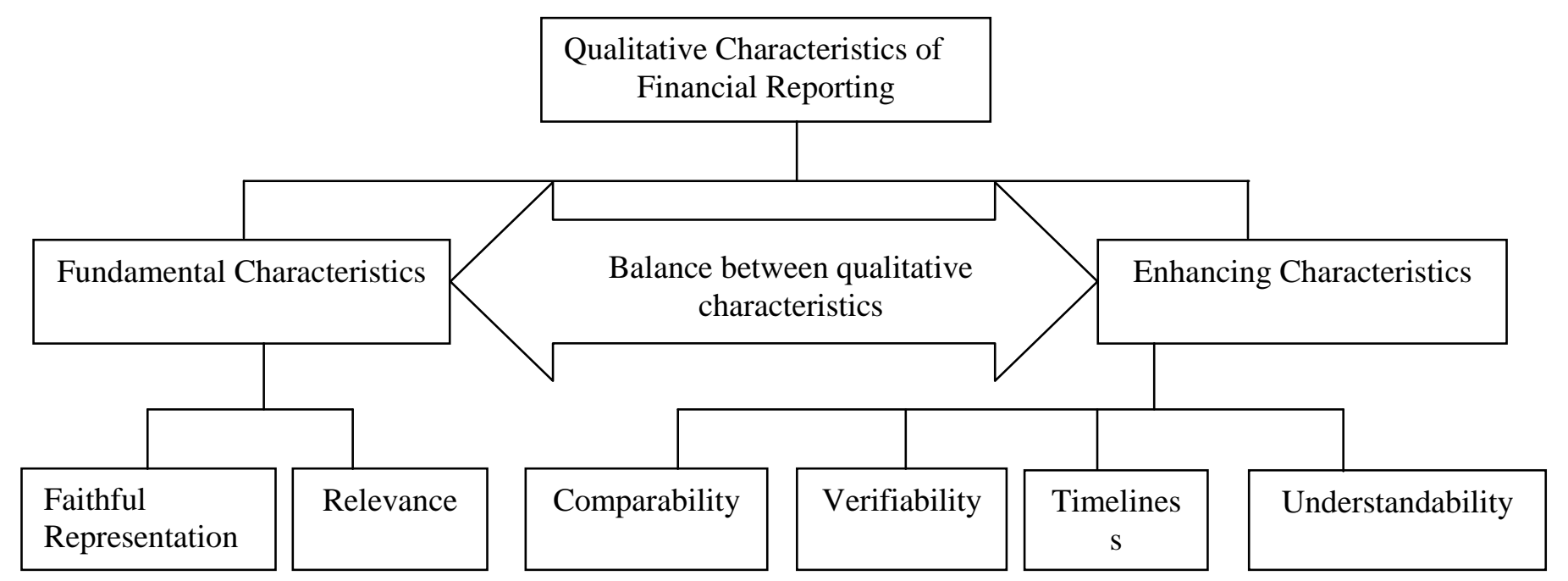

Fig. 1: The qualitative characteristics of financial reporting (IASB 2010)

\section{Empirical Review}

Mahdi and Mohsen (2011) carried out a study on the impact of professional ethics on financial reporting quality in Iran they employed a 24 item questionnaire and worked with a sample of 205 Iranian companies. The result of their findings showed that professional ethics have a significant impact on the quality of financial reporting.

Masoud and Mahbude (2013) investigated the impact of professional ethics on financial reporting quality and found that developing professional ethics in accounting will help promote financial reporting quality. Tae and Jinhan (2011) examined the effect of business ethics on financial reporting quality using Korea firms. They found out that companies with a higher level of ethical commitment are engaged in less earnings management, report earnings more conservatively, and predict future cash flows more accurately than those with a lower level of ethical commitment. We also find that corporate commitment to business ethics has perpetuating effects on future financial reporting quality.

Ogbonna and Appah (2011) investigated the effect of ethics on financial reporting quality in Nigeria using a sample of 123 accountants. The study found out that ethical compliance by the accountant positively and significantly affects the quality financial reports. Agwor and Okafor (2018) conducted a study on ethics and financial reporting quality using a sample of 112 professional accountants using primary data. The results indicate that the presence of ethics has a positive impact on the quality of the judgement made by professional accountants. Berrone, suroca, Tribo (2009) carried out a study using 515 companies using OLS regression analysis. Their study reveals that a strong corporate ethical identity was positively related to high levels of stakeholder satisfaction. In turn stakeholder satisfaction had a positive influence on the financial performance of the firm.

\section{Methodology}

The study adopted a descriptive survey design. This design was selected since the study sought to examine how accounting ethics influence quality of financial reporting. Descriptive design focuses on reporting on the situation as it is which the focus of this study was. This design was applied in this study to report the influence of accounting ethics on quality of financial reports among accounting practitioners in Ibadan, Oyo state. Initial survey revealed that there are about 300 accounting practitioners in Ibadan, Oyo state distributed over deposit money banks, Audit firms, educational tertiary institutions and small and medium scale industries.

The sample size was determined using the Slovin's formula: 


$$
n=\frac{N}{\left[1+N(e)^{2}\right]}
$$

Where $\mathrm{n}$ is the sample size, $N$ is the population size, and e is the margin of error (Babatunde, 2014). Thus, a sample size of 171 was arrived at as follow:

$\mathrm{N}=300$

$\mathrm{e}=$ Margin of error of $5 \%$

$$
\begin{gathered}
\text { Therefore, } n=\frac{300}{\left[1+300(0.05)^{2}\right.} \\
=\frac{300}{[1+0.75]} \quad=171
\end{gathered}
$$

The study employed a combination of convenience and stratified sampling techniques. This ensured a proportionate sampling of all the segments of the population and hence, resulting to representativeness among the selected sample. A sample of 171 respondents was selected where 154 responded.

The study made use of primary data and questionnaires were utilized to collect data for this study. The designed questionnaire had two sections. The first section requested basic demographic information about the respondents. The next section was dedicated to questions in regard to the two dependent variables (relevance and faithful representation of financial information). Five-point likert scale questions were used to assess the accounting ethics and quality of financial reports. The questionnaire was pilot tested before the final drafting. This was done to ensure questionnaire's reliability to obtain the required information (Babbie, 2011). The pilot study involved ten accounting practitioners in Ibadan, Oyo state who did not participate in the final study.

Data analysis was done using Statistical Package for Social Sciences (SPSS) version 22. Inferential and descriptive data analysis techniques were considered in the analysis. Descriptive statistics was done using tables, percentages, and frequency distributions. These were utilized to facilitate a description of various collected data. Inferential statistics was done using regression analysis, which assisted in determining the effects of accounting ethics on financial reports' quality.

The model of the regression was as illustrated below;

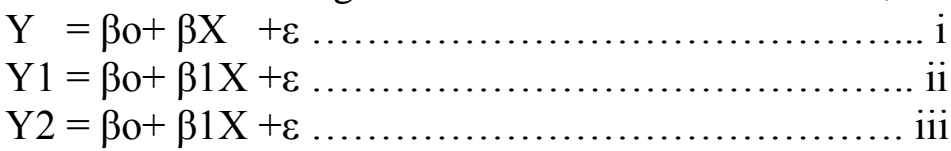

Where,

$\mathrm{Y}=$ Quality of financial reports [Relevance and Faithful Representation]

$\mathrm{Y} 1=$ Relevance

$\mathrm{Y} 2$ = Faithful Representation

$\beta 0=$ Constant

$\beta 1=$ Regression coefficients relating to the accounting ethics

$\mathrm{X}=$ Accounting Ethics

$\varepsilon=$ Error term

\section{Presentation and Analysis of Data}

In analyzing the primary data 154 questionnaires were retrieved from the respondents and are presented in the order of questions raised in the study. The $90.00 \%$ retrieved was alright to meet the objectives of the study.

Table 1: $\quad$ Socio Demographic Characteristics of the Respondents

\begin{tabular}{|l|l|c|c|}
\hline \multicolumn{2}{|c|}{ Category } & Frequency $(\mathbf{N = 1 5 4 )}$ & Percentage (\%) \\
\hline Sex & Male & 106 & 68.83 \\
\hline & Female & 48 & 31.17 \\
\hline & Total & 154 & 100.00 \\
\hline
\end{tabular}




\begin{tabular}{|l|l|l|l|}
\hline Age & Below 25 years & 11 & 7.14 \\
\hline & $26-35$ years & 34 & 22.08 \\
\hline & $36-45$ years & 68 & 44.16 \\
\hline & $\begin{array}{l}46 \text { years and } \\
\text { above }\end{array}$ & 41 & 26.62 \\
\hline & Total & 154 & 100.0 \\
\hline & HND & 38 & 24.68 \\
\hline & B.Sc & 65 & 42.21 \\
\hline & M.Sc & 21 & 13.64 \\
\hline & Ph.D & 17 & 11.04 \\
\hline & Others & 13 & 8.44 \\
\hline Total & 154 & 100.0 \\
\hline Work Experience & $1-5$ years & 10 & 6.49 \\
\hline & $6-10$ years & 48 & 31.17 \\
\hline & $11-15$ years & 31 & 20.13 \\
\hline & $\begin{array}{l}16 \text { years and } \\
\text { above }\end{array}$ & 65 & 42.21 \\
\hline & Total & 154 & 100.0 \\
\hline
\end{tabular}

Source: Field survey 2019

Table 1 above revealed that male has the highest response of $68.83 \%$ while the female response is $31.17 \%$. This indicates that the majority of the respondents under study are male. In addition, the table also showed that the majority of the respondents are within the age range of

$36-45$ years with $44.16 \%$. The result indicates that $24.68 \%$ of the respondents are with HND, $42.21 \%$ are with B.Sc, $13.64 \%$ are with M.Sc, and $11.04 \%$ are with Ph.D degree, while $8.44 \%$ of the respondents are with various types of professional qualifications in the field of accounting. Analysis also indicates that $42.21 \%$ of the respondents have 16 or more years working experience. Inferential data analysis was done using OLS regression techniques. The result of the analysis is presented below:

Table 2: Accounting ethics and relevance of financial information.

\begin{tabular}{|c|c|c|c|c|c|}
\hline Model 1 & $\mathrm{R}=0.830$ & $\begin{array}{l}R^{2}= \\
0.689\end{array}$ & Adj. $R^{2}=0.687$ & $\begin{array}{l}\text { Std. Error } \\
\text { estimation } \\
=0.307\end{array}$ & $\begin{array}{l}\text { Durbin- } \\
\text { Watson = } \\
1.679\end{array}$ \\
\hline \multirow[b]{2}{*}{$\begin{array}{l}\text { Regression } \\
\text { Residual } \\
\text { Total }\end{array}$} & $\begin{array}{l}\text { Sum of } \\
\text { Square }\end{array}$ & Df & Mean Square & $\mathrm{F}$ & Sig. \\
\hline & $\begin{array}{l}6089.24 \\
2744.94 \\
8834.19\end{array}$ & $\begin{array}{l}1 \\
152 \\
153\end{array}$ & $\begin{array}{r}6089.246 \\
18.547\end{array}$ & 328.315 & $.000^{\mathrm{b}}$ \\
\hline \multirow[b]{3}{*}{ Constant } & \multicolumn{2}{|c|}{$\begin{array}{l}\text { Unstandardized } \\
\text { Coefficients }\end{array}$} & $\begin{array}{r}\text { Standardized } \\
\text { Coefficients }\end{array}$ & \multirow[t]{2}{*}{$\mathrm{t}$} & \multirow[t]{2}{*}{ Sig. } \\
\hline & $\mathrm{B}$ & Std. Error & Beta & & \\
\hline & $\begin{array}{r}-11.417 \\
.282\end{array}$ & $\begin{array}{l}2.936 \\
.016\end{array}$ & .830 & $\begin{array}{l}-3.888 \\
18.119\end{array}$ & $\begin{array}{l}.000 \\
.000\end{array}$ \\
\hline
\end{tabular}




\begin{tabular}{|l|l|l|l|l|}
\hline $\begin{array}{l}\text { Accounting } \\
\text { Ethics }\end{array}$ & & & & \\
\hline
\end{tabular}

Source: Author's Data Analysis, 2019

Table 2 shows that accounting ethics $(\beta=0.282, \mathrm{t}=18.119, \mathrm{P}=.000)$ has positive and significant influence on relevance of financial information of Nigerian firms. Furthermore, result reveals that accounting ethics has $68.9 \%$ decisive influence on relevance of financial information of Nigerian firms. The $\mathrm{P}$ value of 0.000 is less than significant level of 0.05 . The result shows that accounting ethics has a significant positive effect on relevance of financial information of Nigerian firms. Therefore $\mathrm{H}_{01}$ is rejected, the research question 1 answered and objective 1 is achieved.

Table 3: Accounting ethics and faithful representation of financial information.

\begin{tabular}{|c|c|c|c|c|c|}
\hline Model 2 & $\mathrm{R}=.809^{\mathrm{a}}$ & $\mathrm{R}^{2}=.654$ & Adj. $R^{2}=.652$ & $\begin{array}{l}\text { Std. Error } \\
\text { estimation } \\
=3.873\end{array}$ & $\begin{array}{l}\text { Durbin-Watson } \\
=1.790\end{array}$ \\
\hline \multirow[b]{2}{*}{$\begin{array}{l}\text { Regression } \\
\text { Residual } \\
\text { Total }\end{array}$} & $\begin{array}{l}\text { Sum of } \\
\text { Square }\end{array}$ & $\overline{\mathrm{Df}}$ & Mean Square & $\mathrm{F}$ & Sig. \\
\hline & $\begin{array}{r}4195.645 \\
2219.689 \\
6415.333 \\
\end{array}$ & $\begin{array}{l}1 \\
152 \\
153\end{array}$ & $\begin{array}{r}4195.645 \\
14.998\end{array}$ & 279.749 & $.000^{\mathrm{b}}$ \\
\hline \multirow{2}{*}{ Constant } & \multicolumn{2}{|c|}{$\begin{array}{l}\text { Unstandardized } \\
\text { Coefficients }\end{array}$} & $\begin{array}{r}\text { Standardized } \\
\text { Coefficients }\end{array}$ & \multirow[t]{2}{*}{$\mathrm{T}$} & \multirow[t]{2}{*}{ Sig. } \\
\hline & $\mathrm{B}$ & Std. Error & Beta & & \\
\hline $\begin{array}{l}\text { Accounting } \\
\text { Ethics }\end{array}$ & $\begin{array}{r}-6.981 \\
.234\end{array}$ & $\begin{array}{l}2.641 \\
.014\end{array}$ & .809 & $\begin{array}{l}-2.644 \\
16.726\end{array}$ & $\begin{array}{l}.009 \\
.000\end{array}$ \\
\hline
\end{tabular}

Source: Author's Data Analysis, 2019

Table 3 reveals that accounting ethics $(\beta=0.234, \mathrm{t}=16.726, \mathrm{P}=.000)$ is independent predictor of faithful representation of financial information of Nigerian firms. The $\mathrm{P}$ value of 0.000 is less than significant level of 0.05 . This shows that accounting ethics has a significant positive effect on faithful representation of financial information of Nigerian firms. Therefore $\mathrm{H}_{02}$ is rejected, the research question 2 answered and objective 2 is achieved. Result also shows that accounting ethics has $65.4 \%$ decisive influence on the faithful representation of financial information of Nigerian firms.

\section{Conclusion and Recommendations}

In this study, the effect of accounting ethics on the quality of financial reports of firms in Nigeria was evaluated. Hypotheses were formulated and tested using data from the administered questionnaires using the Ordinary Least Square regression technique. The analysis of the data showed that accounting ethics had a significant relationship with financial reporting quality. The result is consistent with the study of Ogbonna and Appah (2011) that ethics in the accounting profession is fundamental in the quality of financial reports of organizations. On the basis of the findings, the study concludes that high ethical standard is fundamental in achieving an objective, reliable and transparent financial report. The following recommendations were provided in the study after taking into consideration the study findings;

i. Firms in Nigeria should put in place ethics and compliance department to direct and monitor ethics 
implementation in their day-to-day operations.

ii. Firms reporting structure should adhere strictly to the financial reporting framework issued by the International Financial Reporting Standards for better and more acceptable financial reports.

iii. Accountants as custodians of good financial reports should follow the codes of professional practice issued by the Institute of Chartered Accountants of Nigeria (ICAN) for their day-to-day responsibilities. iv. All the relevant professional accounting bodies in Nigeria should monitor the activities of their members to ensure that codes of ethics are followed in the preparation of quality financial reports in the country.

v. The employment processes of firms should be improved upon so that men and women with high level of ethical standing would be employed.

\section{References}

1. Aguolu, O. (2006). Ethics and integrity in the accounting profession. Nigerian Accountant., 41(3), 54-59.

2. Agwor, T.C. \& Okafor, R. (2018). Accounting Ethics and Financial Reporting Quality of Tourism and Hospitality Firms in Rivers State. Journal of Accounting and Financial Management. 4(3), 1-14.

3. Alexander, D., \& Britton, A. (2000). Financial Reporting. (5th Ed.). London: Thomson Learning.

4. Appah, E. (2010). Ethical accounting standards and societal expectations. International Journal of Social. Policy Issues, 7(1), 53-63.

5. Babbie, E. (2011). The Practice of Social Research (13th ed.). Belmont: Wadsworth Thomson.

6. Carrol, R.A. (2005). Model for ethical education in accounting, In Gowthorpo, C. and Blake J. (Eds.) Ethical Issues in Accounting ( $2^{\text {nd }}$ ed). Taylor and Francis e-Library. 149-164.

7. Catacutan, R. (2006). A humanistic perspective in teaching business ethics in accountancy, paper presented at the 6th Annual Ben-Africa Conference University of Stellenbosch, Cape Town, South Africa 26-28 Strathmore University Nairobi, Kenya, 1-6.

8. Enderl, G. (2006). Confidence in the financial reporting system: Easier to lose than to restore. In: Lu, X and Enderle, G. (Eds.) Developing Business Ethics in China. New York: Palgrave Macmillan.

9. Enofe, A.O., Edemenya, C.C. \& Osunbor, E.O. (2015). The Effect of Accounting Ethics on the Quality of Financial Reports of Nigeria Firms. Research Journal of Finance and Accounting. 6(12), 123-130

10. Filipe, J.A., Alberto, M., \& Ferreira, M. (2011). An ethical issue in anti-commons management aquaculture case in Portugal. International Journal of Academic Research, 3(1), 250-252.

11. Gowthorpe, C. (2005). Ethical issues and the auditor. In Gowthorpe, C. and Blake J (Eds.). Ethical Issues in Accounting (2nd ed.): Taylor and Francis.

12. IASB, (2010). Exposure Draft on an improved conceptual framework for financial reporting: The objective of financial reporting and qualitative characteristics of decision usefulness financial reporting information, London. Pitman Publishing.

13. IFAC, (2005). Building an investment climate of trust: IFAC IFAC's Role and Major Initiatives. FCM Seminar, Cairo, Egypt.

14. Inchausti, B.G. (1997). The influence of company characteristics and accounting regulations on information disclosed by Spanish firms. The European Accounting Review, 1(1), 45-68.

15. International Federation of Accountants Education Committee (2003). International education standards for professional accountants. Available at http://www.ifac.org. 
16. International Federation of Accountants Committee (IFAC) code of ethics (2006)

17. Mahdavikhou, M. (2010). An Investigation into the Effect of Applying Ethics by Accountants on Preparing Reliable Financial Information. M.A. Thesis. Islamic Azad University, Hamedan Branch, Iran, 70-110. Available at: http://www.uic.edu/classes/idsc/ids270sls/likert.htm

18. Mahdavikhou, M. \& Khotanlou, M. (2011). The Impact of Professional Ethics on Financial Reporting Quality. Australian Journal of Basic and Applied Sciences, 5(11): 2092-2096

19. Mahdi, M., \& Mohsen, K. (2011). The impact of professional ethics on financial reporting quality. Australian Journal of Basic and Applied Research, 5(11), 2092-2096.

20. Maines, L., \& Wahlens, J. (2006). The nature of accounting information reliability: inferences from archival and experimental research. Accounting Horizons, 20(4), 399-425.

21. Masoud, B., \& Mahbube, A. (2013). Impact of professional ethics on financial reporting quality. American-Eurasian Network for Scientific Information, 7(10), 2862-2866.

22. Mathews, M.R., \& Perera, M.H.B. (1996). Accounting Theory and Development. South Melbourn, Australia: Thomson Publishing Company.

23. Ogbonna, G.N. (2010). Ethical Considerations in Corporate Governance: A survey of Governance Practices of Corporate Stakeholders in Nigeria. International Journal of Business and Science Research, 1(1), 91-108.

24. Ogbonna, G.N., \& Appah, E. (2011). Ethical compliance by the accountant on the quality of financial reporting and performance of quoted companies in Nigeria. Asian Journal of Business Management, 3(3), 152-160.

25. Rockness, H.O., \& Rockness, J.W. (2010). Navigating the complex maze of ethics. Accounting and the Public Interest, 10, 88-104.

26. Tae, H.C., \& Jinhan, P. (2011). Business ethics and financial reporting quality: evidence from Korea. Journal of Business Ethics 103(4), 403-427.

27. Talebinia, G., Salehi M., \& Jabbarzade, S. (2011). A study of the impact of collapse bon financial reporting quality of listed companies. Some Iranian evidence. African Journal of Business Management, 5(10), 3858-3865.

28. Ramanna, K. \& Sletten, E. (2014). Why do countries adopt International Financial Reporting Standards? Harvard Business School Working Paper, 9-102.

29. Willekens, M. (2008). Effects of external auditing in privately held companies: Empirical evidence from Belgium. International Journal of Academic Research, 5(1), 20-37.

30. Zeghal, D. \& Mhedhbi, K. (2016). An analysis of the factors affecting the adoption of international accounting standards by developing countries. The International Journal of Accounting, 41(4), 373-386. 